\title{
A letter to a rat from a medical student
}

Andrew L.A. Garton, BS

Neurology ${ }^{\circledR}$ 2018;90:186-187. doi:10.1212/WNL.0000000000004852

Our lecture halls speak in chattering keyboards. Every time a teacher says something particularly poignant, helpful, or testable, we all applaud with fingertips on laptops. But today I'm clapping for you, little rat: there is a picture of you on the projection screen, and you are drowning. Feverish notes pop up on every screen: little yellow bubbles reading "learned helplessness," "lack of motivation," and "quicker to give up." Or so I imagine. I'm actually sitting in the front row-this is the first lecture in the last 3 weeks that I have attended. Lately, I've preferred to watch them online, at my own pace, on my own time. But today's topic is "Neurobiology of Depression," and I wanted to hear how my classmates' fingertips would respond. And I wanted to check up on you, little rat.

Little rat, you remind me of a friend I used to have. $\mathrm{R}$ was a girl, a young woman, with a bright smile and hair as dark as the circles under her eyes. She preferred crayons to coloring pencils, she never wore her hair down, and she loved to play field hockey. She loved to win at field hockey. But her glowing smile never quite lit her eyes. Early on in our friendship, I learned that she lived with depression. That she lived despite depression.

Oh rat, you are still drowning, I imagine, but you have been replaced by a slide explaining "Epigenetic Modifications Under Study in Animal Models of Depression." What (I hope) we are supposed to understand is that early life experiences shape the ways that certain genes implicated in psychiatric illnesses are expressed later in life. It turns out that, among rats determined to be genetically vulnerable to developing rat-depression, those who are licked by their affectionate mothers grow up to be phenotypically resilient. They also end up vigorously licking their own offspring as well. Not to demean the findings of the study, which I think are pretty interesting, a sarcastic voice in my head retorts, "So you're saying that even in kids who got the bad genes, they will be saved if their mothers just love them a lot?"

I wonder what R's mom would say. $\mathrm{R}$ was not an easy child to parent: vivacious and charming one moment, supplanted by misdirected anger the next. R's mom would yield, yield, yield, then break; her emotions would spill out as through a break in a dam, swirling with R's until their combined force laid waste to whatever situation they were in. And yet, when $\mathrm{R}$ would wind up in the hospital following one of these levee ruptures, R's mom would bring brownies for everyone on the unit. Did your rat mom love you, little rat? Did she love you as much as R's did? Is that why R resurfaced, clambering out of the rising tide, but you are anchored? Do you need a hand?

Now there are images of rat brain scans on the screen, illustrating the parts of the brain involved in rat-rumination. Apparently, they have ways of knowing whether you little guys ruminate or not. $\mathrm{R}$ told me what that felt like: how it was a spiral of concrete sludge that slowly oozed from the top of her head down her spine into her stomach, poisoning every thought it touched, distracting her from worldly sensations so that she was left alone with only thoughts of selfloathing that carouseled in circles, ricocheting off the walls of her skull, getting louder and louder and meaner and meaner until something would wake her up from her coma and she would realize she was still in the shower, 30 minutes late for school.

What part of the brain does that, Dr. Lecturer?

Oh, the anterior cingulate. Yea, that makes sense actually. Okay. I think we understand each other, little rat.
Correspondence

Andrew Garton

andrew.garton@

columbia.edu

\section{MORE ONLINE}

\section{ค Audio}

Listen to a reading of

Mr. Garton's story.

Npub.org/4ha951 
I bet I have classmates with family members who have fallen prey to cerebrovascular disease, heart disease, diabetes who sat through those lectures waiting anxiously to see if the instructor would say something to help explain everything. I bet I have classmates sitting with me in this room right now who empathize every bit as strongly as I do while you drown, while you literally learn how to be helpless. You go, little rat. Great job being helpless. You have to be helpless so that they can study you and figure out what goes wrong when happiness and joy lose their flavor, the future loses its promise, and life loses its meaning. Can you do that, little rat? For all of us?

$\mathrm{R}$ is not dead. I have not seen her in many years, but I keep in touch with her from afar and I know she is all right. I think, and I do not think she would resent me for saying it, that aging and maturing amid friends and family who supported her gave her the strength to climb out of her pool. She is on medication now, and according to this lecturer we do not even really understand how those work either. We stare into a patient's eyes, dark with depression, and hurl question marks at their head until something recalibrates their neurotransmitters. It's less barbaric than that in practice, I know. But, at times, it no doubt feels that way for patients. I am sorry if it feels that way to you too, little rat, but we do not have a better way yet. I am so grateful for you, little rat. You have made so many sacrifices for medicine, for $\mathrm{R}$, for human understanding. It's twisted, and I know you probably don't have enough neocortex to understand, but you mean a lot to me. I see how you feel, noble rat, I think we can all feel it ourselves. I promise I won't forget you. 


\title{
Neurology
}

\author{
A letter to a rat from a medical student \\ Andrew L.A. Garton \\ Neurology 2018;90;186-187 \\ DOI 10.1212/WNL.0000000000004852
}

This information is current as of January 22, 2018

\section{Updated Information \& Services \\ Subspecialty Collections}

Permissions \& Licensing

Reprints including high resolution figures, can be found at: http://n.neurology.org/content/90/4/186.full

This article, along with others on similar topics, appears in the following collection(s):

\section{Adolescence}

http://n.neurology.org/cgi/collection/adolescence

Depression

http://n.neurology.org/cgi/collection/depression

Pediatric depression

http://n.neurology.org/cgi/collection/pediatric_depression

Information about reproducing this article in parts (figures,tables) or in its entirety can be found online at:

http://www.neurology.org/about/about_the_journal\#permissions

Information about ordering reprints can be found online:

http://n.neurology.org/subscribers/advertise

Neurology ${ }^{\circledR}$ is the official journal of the American Academy of Neurology. Published continuously since 1951 , it is now a weekly with 48 issues per year. Copyright Copyright @ 2018 American Academy of Neurology. All rights reserved. Print ISSN: 0028-3878. Online ISSN: 1526-632X.

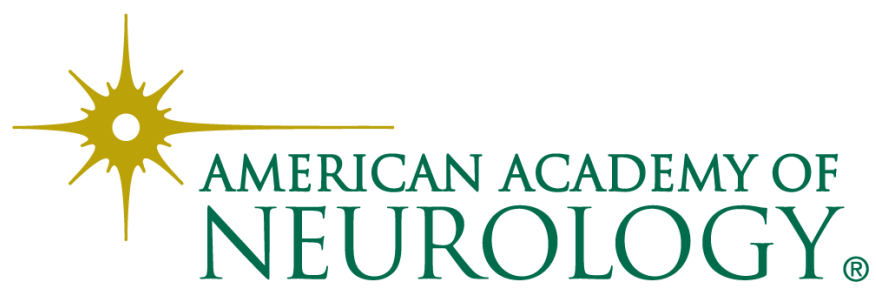

